\title{
NUMERICAL SIMULATION OF NATURAL VENTILATION IN TYPICAL PIGGERY OF SOUTH-EAST CHINA
}

\author{
Mingwei Shen $^{1}$, Yong He ${ }^{*}$, Feilin Hao ${ }^{2}$ \\ ${ }^{1}$ Institute of Biosystems Engneering and Food Science, Zhejiang University, Hangzhou, \\ Zhejing Province, P.R. China 310029,Email:shenhao@zju.edu.cn \\ ${ }^{2}$ Dept. of Environment and public utility, China National Air Separation Plant Corporation, \\ * Hangzhou, Zhejing Province, P.R. China 310004 \\ Corresponding Author. Address: Institute of Biosystems Engineering and Food Science, \\ Zheiang University, Hangzhou 310029, Zheijiang province, P.R.China, Tel:+86-0571- \\ 86971143, Fax:+86-27-86971143, Email:yhe@zju.edu.cn
}

Abstract: In order to understand the airflow pattern of natural ventilation in typical piggery in South-east China, a three dimensional ventilation simulation study was carried out based on the Navier-Stocks Equation by the aid of the fluid dynamics CFX® software. The inlets are mounted in windward sidewall in equidistance along the ridge of the piggery, the airflow guiding passages are set along the roof, on which installed a lambdoidal coping. The sty was incorporated into the simulation model as porous medium, and the factor of outer wind velocity varying with the height was considered. The simulation results shows: there is a significant difference in mass flow of different location of inlets, the central ones is bigger than the side ones. For the guiding openings, the central, right and left account for $64.76 \%, 29.53 \%$ and $5.71 \%$ respectively. The airflow inside the piggery is not even, some anticlockwise and clockwise circumfluence are formed in different direction. The airflow on the vertical plane through the inlets are much intense than that in between. Inside the stys, there displays unbalanced and lower airflow velocity, the average airflow velocity in the right sty is higher than that of the left.

Key words: airflow simulation, natural ventilation, piggery

Please use the following format when citing this chapter:

Shen, M., He, Y. and Hao, F., 2009, in IFIP International Federation for Information Processing, Volume 295, Computer and Computing Technologies in Agriculture II, Volume 3, eds. D. Li, Z. Chunjiang, (Boston: Springer), pp. 2091-2099. 


\section{INTRODUCTION}

The living environment has an important role in affecting health of pig that live inside, and further lead to the economical efficiency of pig production. So the environment control is one of the priorities in piggery management, good-functioned ventilation design could make air be mixed evenly, and help creating a comfortable environment through modulating humidity and air movement. At the same time, the ventilation design should avoid inadequate air velocity and turbulence, which would increase suspended granule, pathogen and accelerate diffusion of ammonia, sulfureted hydrogen, carbon dioxide, etc. and pollute and deteriorate the inside and outside environment.

The industrialized piggery usually equipped with natural and mechanical ventilation system. Forced ventilation mostly works in situation of that natural ventilation could not meet the environment demand such as extreme hot or humid case. In most time of a year, the natural ventilation plays a primary role with the consideration of cost and increased energy stress, so, how to exert the efficiency of the natural ventilation as much as possible deserves main concern.

There are many factors to be considered in natural ventilation, and some factors are highly inter-connected, which makes the theoretical research rather complex. The traditional research concentrates on experiments which compared the featured structural design of natural ventilation systems (M.P. Foster, et al., 1987; B.L. Brockett, et al., 1987; K.J. Andonov, et al., 1989 and 1994; M.T. Karimipanah, et al., 1994 and 1996; K. Andonov, et al., 2003 ,), they did experiments of characteristic piggery and special design natural ventilation systems, studied the method of ventilation control to the effect of the airflow pattern, etc. With the development of computing technology, the computational fluid dynamics (CFD) provide a powerful tool in simulation airflow movement for greenhouse and barn.

In order to have a better understanding of the typical ventilation arrangement on the effect of airflow in South East China region, based on Navier-Stocks Equation and by the aid of fluid dynamics CFX ${ }^{\circledR}$ software, three dimensional steady simulation were undertaken to analyze and evaluate the air movement inside the piggery. The understanding of the detailed airflow movement inside could help enhancing the environment management and make better living condition for the pig growth.

\section{VENTILATION THEORY}

The ventilation theory is based on Navier-Stocks Equation (Mingwei.Shen et al., 2004; CFX Handbook Ver. 5.6. 2002.), after setting up parameters of 
initial value and boundary conditions, the software $\mathrm{CFX}^{\circledR}$ is used in resolving the relations.

The existence of sty would undoubtedly affect the surrounding airflow intensity. The method that uses to describe porous medium "DarcyForcheimer" Equation is applied in this case to approximate this effect (Mingwei.Shen et al., 2004):

$$
-\frac{\partial p}{\partial x_{i}}=\frac{\mu}{K} U_{i}+K_{\text {loss }} \rho|\vec{U}| U_{i}
$$

$-\frac{\partial p}{\partial x_{i}}$ is pressure gradient; $\rho$ is fluid density; $\mu$ is fluid dynamic viscosity; $U_{i}$ is airflow velocity; $K$ is medium penetration ability; $K_{\text {loss }}$ is non-linear momentum lose parameter.

The piggery that constructs comparatively high to achieve better natural ventilation effect, to achieve a more precise simulation result, the outer wind velocity change along different height are also taken into consideration (A. Shklyar et al., 2004) in this case.

$$
U_{\text {wind }}=\frac{u_{\text {fric }}}{K} \ln \left(\frac{z+z_{0}}{z_{0}}\right), \quad u_{\text {fric }}=\frac{K u_{h}}{\ln \left(\left(h+z_{0}\right) / z_{0}\right)}
$$

$U_{\text {wind }}$ is outside wind velocity; $u_{\text {fric }}$ is frictional wind velocity; $K$ is Von Karman constant $(=0.42) ; z, z_{0}$ is the height in y direction, in which $z_{0}$ denotes ground surface coarseness, which takes the value of $0.01 \mathrm{~m}$ (Bartzanas et. al., 2004) with referring to agrarian surface; $u_{h}$ denotes the reference wind velocity, which takes the average value of summer time in Hangzhou City; $h$ is the height of reference wind velocity.

\section{AIRFLOW SIMULATION}

The simulation is taken in a widely used and typical piggery in South East China, which has span length is $8.0 \mathrm{~m}$, eave height $2.5 \mathrm{~m}$, ridge height $3.72 \mathrm{~m}$, roof gradient $4: 12$, transom window height $4.36 \mathrm{~m}$, piggery length $32 \mathrm{~m}$. The sty is assembled with the height of $1.0 \mathrm{~m}$, length of $3.35 \mathrm{~m}$, the width could be adjusted according to pig growth requirement. Fig. 1 shows the structural view of the piggery, there lay equably 10 rectangular inlets in windward sidewalls, with the size of $1.6 \mathrm{~m} \times 0.4 \mathrm{~m}$ each. Outlets lay along the transom window, with the width of $0.4 \mathrm{~m}$ and have lambdoidal protection cap above, airflow guide board are laid along the roof. The simulation is extended to a 
wide scope of $48.0 \mathrm{~m}$ (Length) $\times 40.0 \mathrm{~m}$ (Width $) \times 6.4 \mathrm{~m}$ (Height) to achieve a more accurate estimation of the surrounding airflow movement.
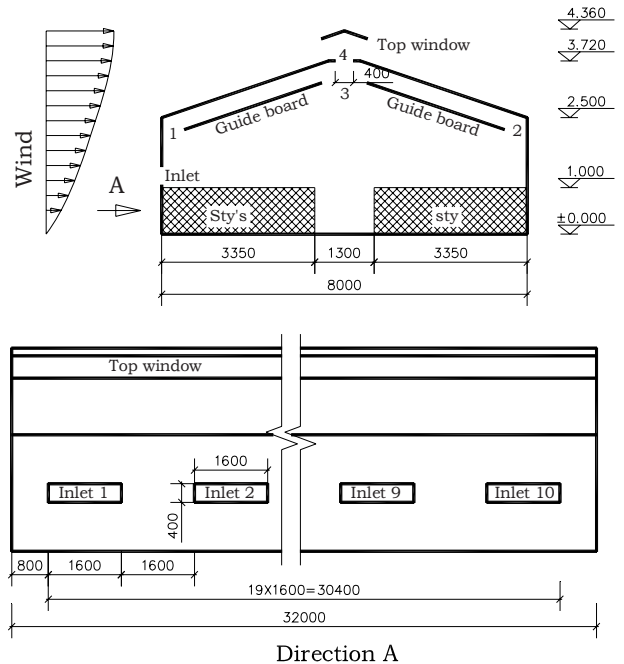

Fig. 1: Schematic view of pig house

Limited cell gridding is the basic unit for CFD resolution, so in the first place, the space inside and outside of the piggery should be partitioned to form cells. Fig. 2 shows the mesh in overall and partial region, it could be seen that the area within and surrounding ventilation windows (inlets and outlets) lie higher density of cells, which is in an effort to simulate the local airflow fluctuation better. In consideration of friction and cut effect, the cell are partitioned into thinner 5 layers in all walls, airflow guide board, sty boundaries, ground etc. to meet the non-slippage model.

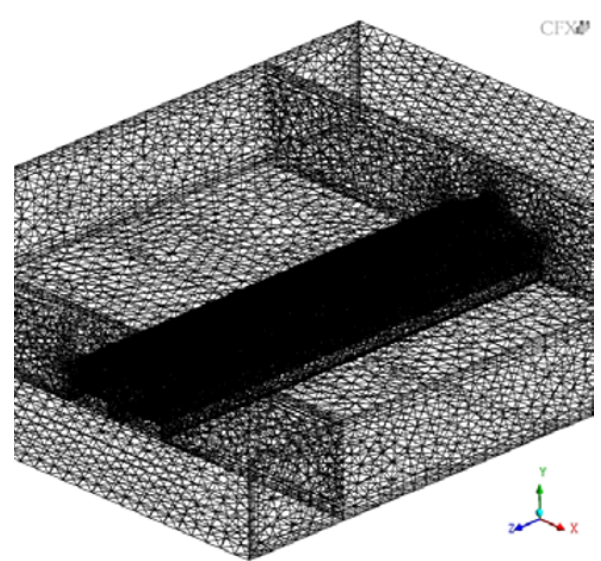

(a) Overall meshing arrangement

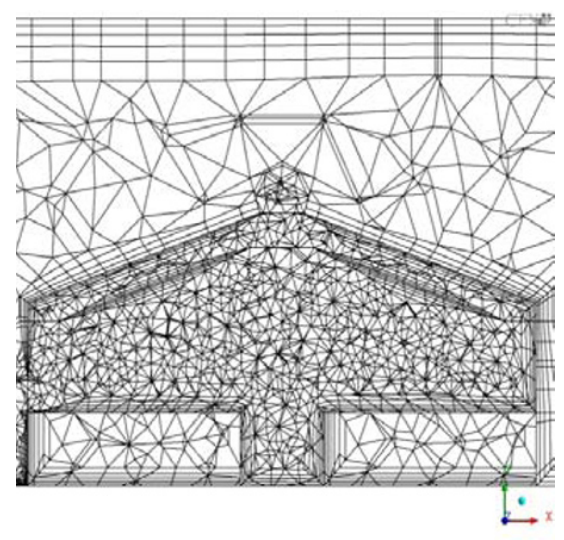

(b) Local meshing arrangement

Fig.2: Schematic view of CFD mesh for pig house 
In consideration of structural characteristic and environment condition, some basic parameters and intuition condition is set in table 1., the simulation result of different sections is shown in Fig. 3 to 5 .

Table 1. Some basic parameters and initial condition of the model

\begin{tabular}{|c|c|c|c|}
\hline Variable & Value & Variable & Value \\
\hline Initial value: & & Computational mesh: & \\
\hline Reference Pressure & $101325 \mathrm{~Pa}$ & Mesh type & Tetrahedron mesh \\
\hline $\begin{array}{l}\text { Reference } \\
\text { temperature }\end{array}$ & $298.15 \mathrm{~K}$ & Maximum mesh size & $\begin{array}{l}1000 \mathrm{~mm} \text { (surrounding } \\
\text { space of the piggery), } \\
500 \mathrm{~mm} \text { (within the } \\
\text { piggery), } 100 \mathrm{~mm} \text { (within } \\
\text { area of ventilation } \\
\text { windows) }\end{array}$ \\
\hline Turbulent degree & $5 \%$, medium & $\begin{array}{l}\text { Mesh expanding } \\
\text { control: control } \\
\text { suface/layer/proportio } \\
\text { n factor }\end{array}$ & $\begin{array}{l}\text { Walls including both } \\
\text { inside and outside of the } \\
\text { piggery, sty } \\
\text { boundaries } / 5 / 1.3\end{array}$ \\
\hline$u_{h}$ & $\begin{array}{l}1.85 \mathrm{~m} / \mathrm{s} \text { (average } \\
\text { wind velocity of } \\
\text { Hangzhou city) }\end{array}$ & Others: & \\
\hline$h$ & $\begin{array}{l}10.0 \mathrm{~m} \text { (the height of } \\
\text { anemoscope) }\end{array}$ & Turbulent model & $\mathrm{K}-\varepsilon$ \\
\hline $\begin{array}{l}\text { Boundary } \\
\text { condition: }\end{array}$ & & $\begin{array}{l}\text { N-S Equation discrete } \\
\text { format }\end{array}$ & $\begin{array}{l}\text { Self-adaption two factorial } \\
\text { windward format }\end{array}$ \\
\hline $\begin{array}{l}\text { Wall surface(fixed } \\
\text { boundary) } \\
\text { condition }\end{array}$ & $\begin{array}{l}\text { Lubricity, non- } \\
\text { slippage model }\end{array}$ & $\begin{array}{l}\text { N-S Equation } \\
\text { resolution method }\end{array}$ & $\begin{array}{l}\text { Overall: AMG } \\
\text { acceleration ILU } \\
\text { iteration; velocity and } \\
\text { pressure: SIMPLEC } \\
\text { method }\end{array}$ \\
\hline Inlet & $\begin{array}{l}\text { Hexahedron } \\
\text { windward surface of } \\
\text { piggery periphery }\end{array}$ & $\begin{array}{l}\text { N-S Equation } \\
\text { resolution } \\
\text { precision(average } \\
\text { radical sign error) }\end{array}$ & $\mathrm{RMS}<0.0001$ \\
\hline $\begin{array}{l}\text { Openings(inlet\&ou } \\
\text { tlet) }\end{array}$ & $\begin{array}{l}\text { Hexahedron leeward } \\
\text { surface of piggery } \\
\text { periphery }\end{array}$ & & \\
\hline
\end{tabular}

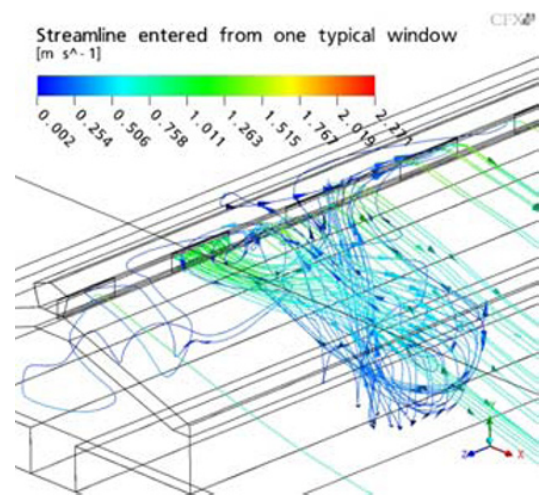

(a) Air entered from one typical window

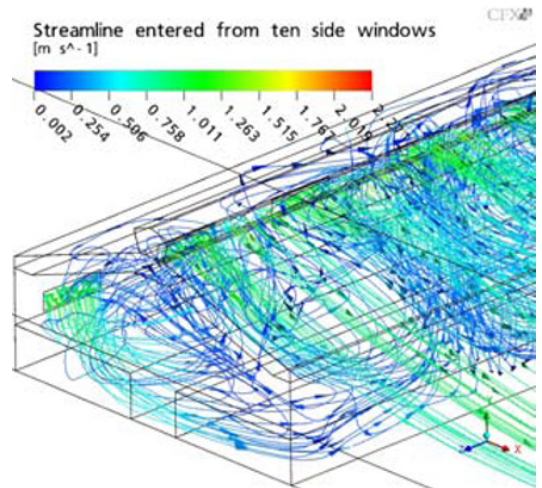

(b) Air entered from ten side windows

Fig.3: Simulated airflow streamlines entered from inlets 

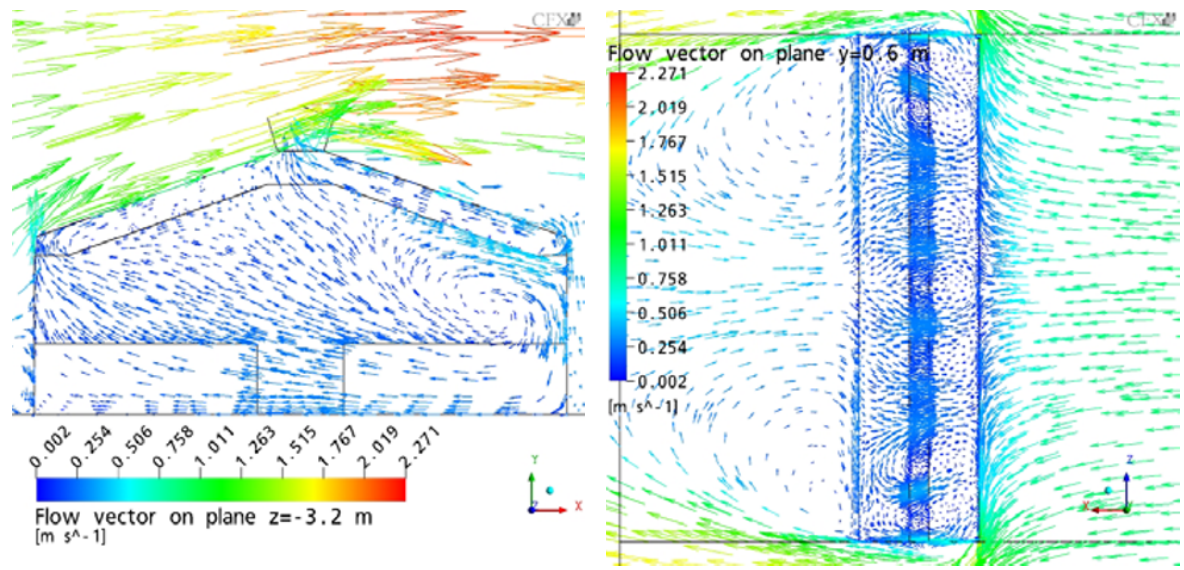

Fig.4: Simulated airflow vector on some typical sections

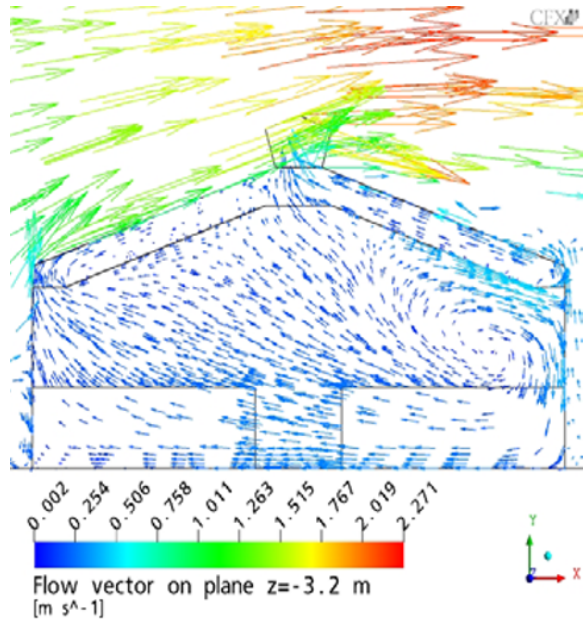

(b) Section through no windows

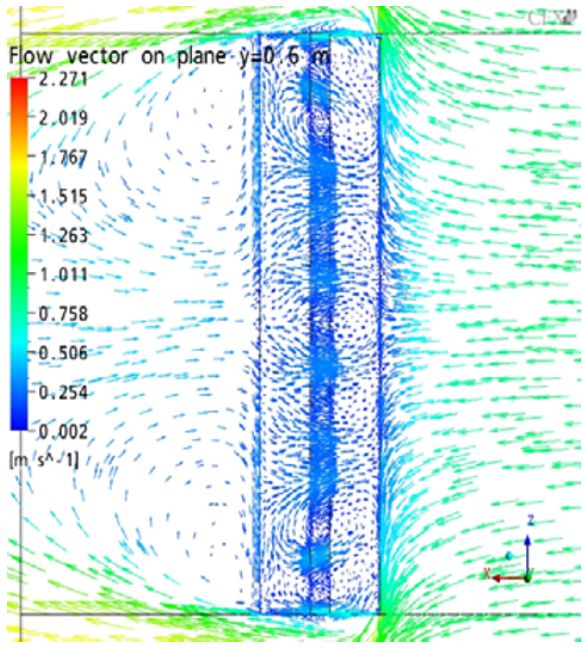

(b) Horizontal section through pig columns

Fig.5: Simulated airflow vector on typical sections

Table 2. shows some statistical value of several typical regions, it could be seen that the different position inlets along the sidewall have different air flux, the central location has relatively higher and the outskirts lower, the maximum difference is $2.15 \%$ to total inlet flux, the average mass flux is $0.00682 \mathrm{~kg} / \mathrm{s}$, The airflow displays symmetrical basically along the sidewall. The difference is obvious in three guiding opening above, in which $64.76 \%$ of total outflow is through the central one (flow guiding opening 3), $29.53 \%$ of total is through right one (flow guiding opening 2), only $5.71 \%$ is through left one (flow guiding opening 1). There is difference in airflow velocity 
inside the piggery, the area within the sty area is relatively slower and outside quicker, the average airflow velocity for outside area of the sty is $0.25 \mathrm{~m} / \mathrm{s}$. The difference could also be observed in left and right side sty, the average airflow velocity is $0.21 \mathrm{~m} / \mathrm{s}$ and $0.16 \mathrm{~m} / \mathrm{s}$ for right and left sty respectively, it could still satisfy the requirement of pig growth in terms of airflow velocity (Derang $\mathrm{Wu}, 1994)$.

Table 2. Statistic data in some typical regions of the pig house

\begin{tabular}{|c|c|c|c|}
\hline $\begin{array}{c}\text { Ventilation } \\
\text { window/region }\end{array}$ & $\begin{array}{c}\text { Average mass } \\
\text { flux } / \text { velocity } \\
(\mathrm{kg} / \mathrm{s} / \mathrm{m} / \mathrm{s})\end{array}$ & Ventilation window/region & $\begin{array}{c}\text { Average mass } \\
\text { flux/velocity } \\
(\mathrm{Kg} / \mathrm{s} / \mathrm{m} / \mathrm{s})\end{array}$ \\
\hline Inlet 1 & $0.00589 \mathrm{~kg} / \mathrm{s}$ & Inlet 10 & $0.00592 \mathrm{~kg} / \mathrm{s}$ \\
\hline Inlet 2 & $0.00672 \mathrm{~kg} / \mathrm{s}$ & Flow guiding opening 4 & $0.23955 \mathrm{~kg} / \mathrm{s}$ \\
\hline Inlet 3 & $0.00699 \mathrm{~kg} / \mathrm{s}$ & Flow guiding opening 1 & $0.00436 \mathrm{~kg} / \mathrm{s}$ \\
\hline Inlet 4 & $0.00723 \mathrm{~kg} / \mathrm{s}$ & Flow guiding opening 2 & $0.02252 \mathrm{~kg} / \mathrm{s}$ \\
\hline Inlet 5 & $0.00722 \mathrm{~kg} / \mathrm{s}$ & Flow guiding opening 3 & $0.04938 \mathrm{~kg} / \mathrm{s}$ \\
\hline Inlet 6 & $0.00736 \mathrm{~kg} / \mathrm{s}$ & $\begin{array}{l}\text { Upper guiding aisle of } \\
\text { piggery }\end{array}$ & $0.159 \mathrm{~m} / \mathrm{s}$ \\
\hline Inlet 7 & $0.00722 \mathrm{~kg} / \mathrm{s}$ & Inside space of piggery & $0.251 \mathrm{~m} / \mathrm{s}$ \\
\hline Inlet 8 & $0.00700 \mathrm{~kg} / \mathrm{s}$ & Left side of sty & $0.166 \mathrm{~m} / \mathrm{s}$ \\
\hline Inlet 9 & $0.00666 \mathrm{~kg} / \mathrm{s}$ & Right side of sty & $0.214 \mathrm{~m} / \mathrm{s}$ \\
\hline
\end{tabular}

Fig.3(a) shows the airflow movement coming through the inlet 2 (in order to be more clearly displayed, the airflow from the other inlet are hidden in this case). Fig.3(b) is the overall airflow movement inside the piggery. It could be seen the overall airflow is basically symmetrical along the ridge, while the airflow coming through inlet 1 and 10, the inlet 2 and 9, and the remaining inlets are different. The airflow from the inlet 1 or 10 is divided into two branches, of which one remains at the height of inlet and a bit of leaning to the nearer frontispiece, flow in the direction to the opposite sidewall, it decreases to about $1 / 2 \sim 1 / 3$ when it arrives the right sty, then turns back, deviates to the nearer frontispiece and flow upward, finally the majority are flow out through central guiding opening, the remain is out through the left guiding opening; The other that flow downward also lean a bit to the nearer frontispiece, flow into the left sty in about half length of left sty, continue flow forward to the right sty, the airflow velocity decreases gradually to about $1 / 10$ of the inlet, turns back and deviates to flow upward, finally the majority of airflow move out through central guiding opening and the remain through the left one. There presents two obvious circumfluence which permeate most space of the piggery, the airflow in the left sty is less than the right one, the distribution is not even.

Fig.3 and Fig.4(b) shows the airflow movement coming from inlet 2 and 9, it could be seen that the incoming air flows slowly and slightly to the neighboring frontispiece, on the whole, it does not flow into the left sty, the part that airflow influx into right sty are distributed in partial above space. 
When the airflow arrive at the opposite sidewall, the majority turn back and upward to flow out of the piggery through right guiding opening, the remaining which has velocity less than $0.1 \mathrm{~m} / \mathrm{s}$ form large and mild turbulence, finally flow out the central and right guiding opening.

The airflow movement inside the piggery coming from inlet 3 to 8 is approximately similar. The incoming airflow deviates slightly in horizontal plane (XY plane) and flows in a direction of upward. These airflow flow through mostly above the stys, when arriving the opposite sidewall, some flow forward and out from right guiding opening, much more airflow turn downward to flow into right sty, in which some turn back to flow forward, some flow through sty, finally flow out from piggery through central and left guiding openings. The intensity of airflow movement in left sty is less than that of the right one, but much more even.

The Fig.5 shows the airflow movement on vertical plane between two inlets and horizontal plane $0.6 \mathrm{~m}$ above the ground, the one of $0.6 \mathrm{~m}$ is selected to better represent the pig growth living area. The overall airflow in vertical plane through the inlet is more intense than that of in between one, which is more so in two side of the piggery.

\section{RESULT AND DISCUSSION}

From the simulation result, the airflow movement is basically symmetrical along the ridge direction. There is difference in mass flow of different location of inlets, the central ones is bigger than the side ones, the maximum difference is $2.15 \%$ to total inlet flux.

The three guiding opening is functioning differently, in which the central one accounts for more than half of the total airflow flux, the right one lays second and that is less than the half of the central one, the left one the is least and that is about $1 / 11$ of the central one.

There shows three different fluxions after air flow into the piggery, the air coming into from inlet 1 and 10 have the characteristics of downward and inclining to nearer frontispiece, the air that coming into from inlet 2 and 9 would flow downward, some small part would flow in the direction to the nearer frontispiece, the anticlockwise circumfluence are form in opposite $\mathrm{Z}$ direction. The air coming from inlet 3 to 8 see less deviation from the horizontal plane (XY plane), move slightly upward and forms clockwise circumfluence in the direction of opposite $\mathrm{Z}$ direction.

The airflow inside the piggery are not even, the airflow on the vertical plane through the inlets are much intense than that in between, the area of the middle aisle is the most intensive. In consideration of the two side stys, the average airflow velocity in the right side is higher than that in the left, all could meet the airflow requirement of pig growth. 
From the overall ventilation status, the airflow movement is much higher and even in non-living surroundings of the piggery, and shows lower velocity and unbalanced inside the stys, which could arose dirt, accelerate production and diffusion of poisonous gas, and pollute the environment both inside the piggery and outside. There still exists some place that need to be improved in terms of ventilation design.

\section{ACKNOWLEDGEMENTS}

Funding for this research was provided by the Natural Science Foundation of Zhejiang Province, China (Project NO: Y307166). Education Office of Zhejiang Province, China (Project NO: 20070128).

\section{REFERENCES}

A. Shklyar, A. Arbel. Numerical model of the three-dimensional isothermal flow patterns and mass fluxes in a pitched-roof greenhouse. Biosystems Engineering, 2004, 88(4):479 940

B.L. Brockett, T.D. Albright. Natural ventilation in single airspace buildings. Journal of Agricultural Engineering Research, 1987, 37:141 154

CFX. 2002. CFX Handbook Ver. 5.6. U.K. CFX Company.

Derang Wu. Agricultural Architectonics[M], Agricultural Publishing House, Beijing, 1994

K. Andonov, P. Daskalov, K. Martev. A new approach to controlled natural ventilation of livestock buildings. Biosystems Engineering, 2003, 84(1): 91 100

K.J. Andonov, P.I. Daskalov, K.V. Martev. Microclimate system for livestock building with controlled narural ventilation. Agricultural Engineering, 1989, 2:55 62

K.J. Andonov. An aeration configuration in a stock breeding building. Agricultural mechanization, 1994, 5:16 18

M.P. Foster, M.I. Down. Ventilation of livestock buildings by natural convection. Journal of Agricultural Engineering Research, 1987, 37:1 13

M.T. Karimipanah, M. Sandberg. Deflection and influence of room-size of a two-dimensional wall jet in a ventilated room. Proceeding of ROOMVENT'94, Fourth International Conference on Air Distribution in Rooms, 15 17, June, 1994, Krakow, Poland

M.T. Karimipanah, M. Sandberg. Maximum velocity of return flow close to the floor in a ventilated room-experimental and numeric results. Proceedings of the 17th AIVC Conference, 17 20, September, 1996, Gotenburg, Sweden

Mingwei.Shen, Feilin.Hao. Simulation of natural ventilation of two wind direction in tunnel greenhouse. Journal of Agricultural Engineering, 2004, 20(6): 227 232 tation. 